DOI https://doi.org/10.18551/rjoas.2018-02.24

\title{
PARTICIPATIVE MAINTENANCE OF UPSTREAM PUSUR SUB WATERSHED AREA THROUGH THE CONSERVATION FIELD SCHOOL IN MRIYAN VILLAGE OF BOYOLALI DISTRICT, INDONESIA
}

\author{
Afandi Muslim*, Suwarto, Lestari Eny \\ Community Empowerment Study Program, Sebelas Maret University, Indonesia \\ *E-mail: musliminafandi@gmail.com
}

\begin{abstract}
ABTRACT
This research is done to describe the process of participative maintenance by conservation field school the upstream area of Sub Watershed Pusur. This research used qualitative approach with descriptive strategy in Mriyan Villages Sub District Musuk District Boyolali. The data collection techniques used for research are interview method, focus group discussion and participative observation. The people of Mriyan's support is actualized in the form of conservation field school, the effort and the decision making, that are actively in charge in social learning, net working, and maintaining the resource of thee people.
\end{abstract}

\section{KEY WORDS}

Conservation field school, participative maintenance, upstream area, sub watershed pusur, farmer.

The river stream area simply meant as an area where the water flow from the upstream to downstream. If we follow the policy of the law that have been realized by the government which is the 'UU No.7 Tahun 2004, watershed is understood as a landmass that are one in unity with the river and its creeks and it has the function to naturally contain, saving, and flow the water from rainfall into the lake or the sea. Physiographically (Geomorphology) watershed is classified into three kind of area. First is the upstream area. This area has the characteristic as a production area or commonly known as water infiltration area. Second is the middle stream area. These areas function as a metrial distributor that is produced from upstream area. Third is the downstream area. Coming from the maintenance issue mentioned above, there are things that need to be examined regarding Sub Watershed Pusur. The sub watershed Pusur area span across the upstream until the downstream where the downstream is located in the Sub- District Juwiring area and the Sub-District Delanggu, District Klaten, Central Java Province, that ended into the primary stream of Bengawan Solo River and is the middle tranverse part of Sub-District Polanharjo and the Sub-District Tulung District Klaten. While, the upstream part span upward in Sub-District Musuk District Boyolali (BPDAS Solo: 2015).

Ever since 2003, comunity based program and activities with the regard of the Sub Watershed Pusur maintenance was initiated. The development can only touch those in downstream and middle area. Some institution and community element have intervene on the subject. The performance that was conceptualized have been referring to one plan and one policy. However, the reinforcement in the upstream area is not really touched and it tend to be ignored. In role, upstream area is the supporting area and also the water absorption area (production function). If it is not touched and centralized, the impact will be the unbalanced ecosystem of upstream, middle, and downstream area. Talking about upstream area, the condition of upstream area in sub watershed Pusur is having quite a change across time. The condition of ecosystem degradation is also been worsened by the increased number of critical land in the village of that upstream area (Chay Asdak: 2014).

One that becomes a concern is Mriyan village. The condition of the critical land in Mriyan village can reach into 269.6869 ha. With the critical land composition reaching the number 115.7875 ha and land with critical potential within 153.8710 ha. This number is increasing looking back at the last two years. The number of critical land that is increasing is also affected by the intensity of disaster that is increasing every year. From the eruption of 
Merapi in 2010, Mriyan village is known as the village that brought the biggest erosion chunk and landslide (BPBD Boyolali: 2014). The great amount of point with the $45^{\circ}$ slope, and the absent of vegetation cover caused by the tobacco commodity in the villager's land. With the emergence of this various problems, it will threaten the living system of the community. Thus, periodical assistance and the awareness of natural conservation are needed. One of the suggestion that are deemed as fitting is the 'Conservation field farmer' that have been running since 2016.

\section{METHODS OF RESEARCH}

This research is done in Mriyan village Musuk Sub-District Boyolali Regency. The location is chosen in accordance to some reason: (1) Mriyan village is a water catchment area, (2) Mriyan village is an upstream area with the potential of the largest area in comparison with other village in upstream area of Sub Watershed Pusur that serve as a production area and the support location in the middle and the downstream, (3) it has a significant problem from the high number of critical land, the high number of disaster intensity, and the decrease in the erosion defensive vegetation, (4) The receiver and the participant community that support the conservation program in the Sub Watershed Pusur area. From the study on the problem that are present in the area of Mriyan Village and the program that have already been initiated from 2015, researcher understand deeply in regard to any social dynamic that are present using the approach of qualitative descriptive research. The data source that is used is data taken from the actual site (primer) and data taken from document, archive, and documentation result in accordance to the research (Deddy Mulyana: 2001). This research is done with the duration of 11 month from December 2016 to October 2017. For the success of this research, the research employ the research technique with in-depth interview, observation with participation, Focus group discussion (Jerome Kirk and Marc L. Miller,: 1985). For the validation of data, this research is strengthened by the triangulation technique. In deciding the research subject, the researcher is leaning toward "purposive sampling" or commonly known as "criteria based selection" (Goetz \& Le Compte: 1984). The researcher position is to choose purposively based on various judgment and criteria determined by the researcher. There are certain rules and standardization for deciding the informant subject. The data processing and analysis use Miles and Huberman analysis method.

\section{RESULTS AND DISCUSSION}

Mriyan Village and Sub Watershed Pusur Condition. In administration, Mriyan village is located in Musuk Sub District and Boyolali District Central Java Province. It is surrounded by national forest under the management of Merapi Volcano National Park. Hidrologically, it is included as an upstream area of Sub Watershed Pusur. The distance it has from Mount Merapi is $5 \mathrm{~km}$, causing a high potential of eruption disaster in the area. It has been included as an area of extreme disaster awareness I.

Table 1 - The Mriyan village usage of land

\begin{tabular}{|c|c|c|}
\hline Number & Land Use & Total \\
\hline 1 & Yard/Building / Emplacement & $59.3225 \mathrm{ha}$ \\
\hline 2 & Farm / Garden & $153.8715 \mathrm{ha}$ \\
\hline 3 & Prairie area & $25.0000 \mathrm{ha}$ \\
\hline 4 & Forest land & $15.0000 \mathrm{ha}$ \\
\hline 5 & Others (Graveyard / public facility / social) & $31.4650 \mathrm{ha}$ \\
\hline \multicolumn{2}{|c|}{} & $284.6590 \mathrm{ha}$ \\
\hline 6 & Total & $36.9605 \mathrm{ha}$ \\
\hline 7 & Bended land/Village inventory & $153.8710 \mathrm{ha}$ \\
\hline 8 & Potentially Critical land & $115.7875 \mathrm{ha}$ \\
\hline
\end{tabular}

Data source: Mriyan Village Monograph, 2016. 
The height that reach 1,342 ha place Mriyan village as the highest along the hidrology line of the Sub Watershed Pusur. It is also an area with 284,659 wide of water catchment area in comparison with other village that are in the upstream Sub Watershed Pusur area.

The hilly location and the steep cliff that are more than $15 \%$ indicate an appropriate location for conservation intervention. The condition of the problem is also apparent with the high of critical land number that is present in Mriyan Village. From the table1, it is explained that the area of the land with critical condition can reach the number of 153.8710 ha. While the land with critical condition can reach 115.7875 ha. With the area that are divided into three hamlet. There are 21 household with 3,219 people, with profession dominated by farmer. Other people do trading, civil servant, and work in private sector. The condition of spatial conditioning of Mriyan village is divided by hamlet. I, II, III is bordered by cliff with high rate of slope. Because of that, to access the inter-hamlet location we have to cross the cliff first. The prized commodity of the people is tobaccos. While, for the daily need the people is heavily helped by sprinkled rose flower. Nearly every farmer in the area of Mriyan village sell Rose flower. Every day, they sell it by Rp. 15.000 - Rp. 20.000 / 2 Kg.

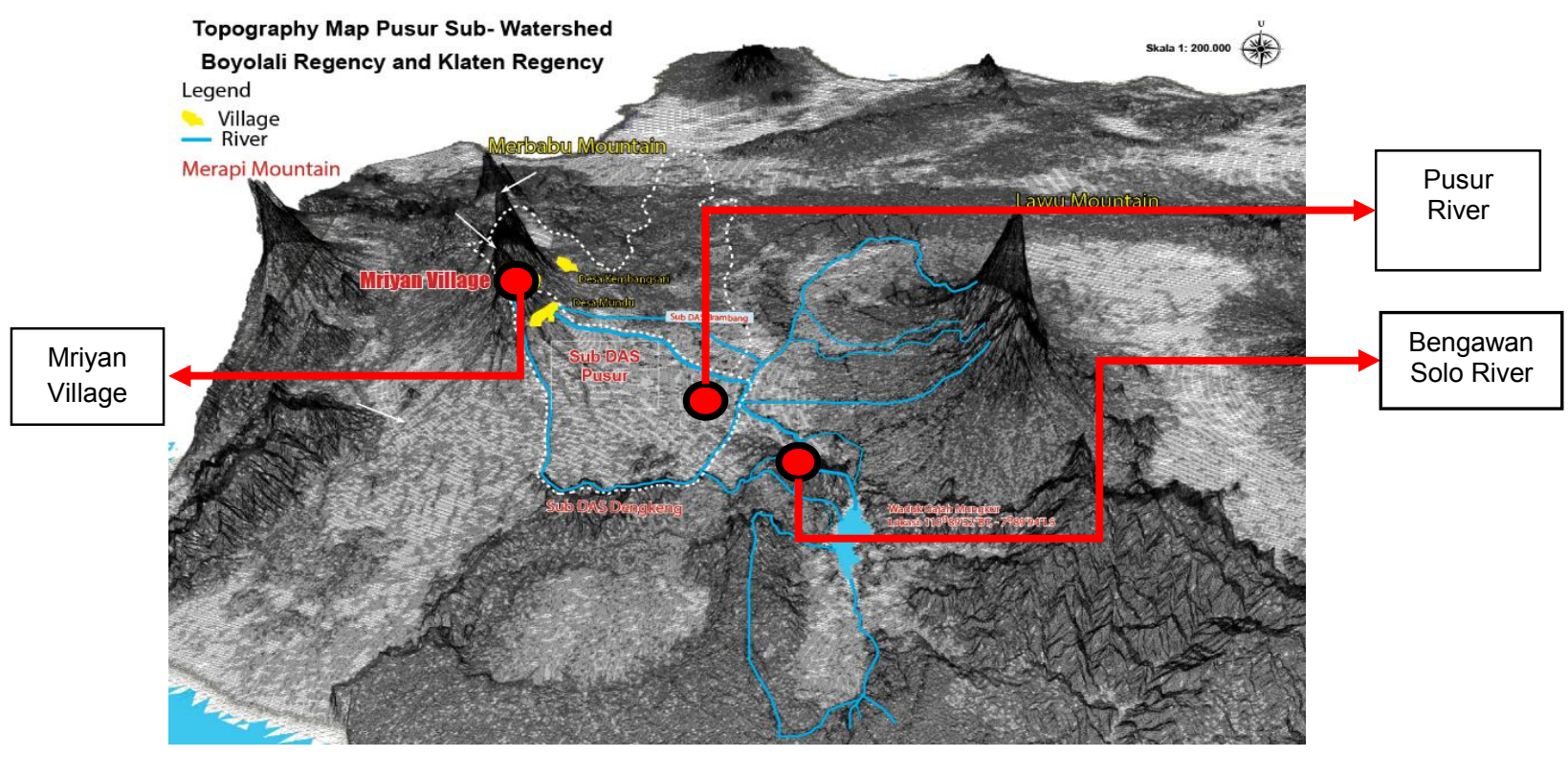

Picture 1 - Topography Map of Sub Watershed of Pusur

Mriyan village position with the most upstream topography is important for the conservation of Sub Watershed Pusur. In general Sub Watershed Pusur is known locally as Pusur river. It span across $36,576 \mathrm{Km}$. Pass by Klaten and Boyolali in the Central of Java. The river divided into several parts. The upstream is on Musuk regency, Boyolali; the mainriver on Tulung regency; and downstream on Delanggu, Juwining and Wonosari regency, Klaten. Pusur is categoried as a small river because of its width. The average width for a river is 7-10 $\mathrm{m}$ (Heinrich dan Hergt, 1998). The estuary of Pusur intersects to Bengawan Solo, the biggest river in Java. As part of watershed, a strong affinity in Pusur is needed because the river is expected to balance the ecosystem around it.

Pusur Sub Watershed Management Through Conservation Field School. Indeed there are activities focusing on the environment of Pusur since 2003. Those activities are the result of cooperation with local government and PT. Tirta Investama Klaten with their CSR (Cooperate Social Responsibility) program. All of the activities are partials, an integrated participation among upstream area, downstream area and main-river area is not yet happen. Hence, an idea to manage the upstream area of Pusur watershed appears.

There are activities that could be implemented for this problem. To manage Pusur watershed can not be done partially. Indeed, it needs involvement from stakeholders, e.g. private institutions, local organizations and government. Other than that, it also needs a party to organizing the stakeholders. This party will be the one to unite and communicate between 
parties in order to manage Pusur watershed, and there are Klaten River School and Boyolali River School, Public Work Services, Agriculture and Plantation Services, Tourism Services and villages alongside Pusur riverbanks. Implementation for this work starts with study of Pusur watershed using transect method in a participatory manner. It starts from upstream area to main-river area $(36 \mathrm{~km})$. The purpose for this comprehensive study is to provide the latest data of Pusur. We expected this process to unite parties into a mutual interest.

From some intensive meetings held by the stakeholders, eventually some parties (local government and volunteer communities) came with an idea to form an official institution. The purpose of the institution is to balancing every parties concern regarding their needs of Pusur. The first organizer discussed about activities around Pusur. The upstream area focusing on ground and water conservation, the main-river on waste disposal and water management, the downstream focusing on preventing flood and water management. On February $18^{\text {th }} 2017$, an institution for discussing problem around Pusur is formed. Each area will have their responsibility to preserve Pusur. This institution is called as "Pusur Institute", a forum to discuss their knowledge regarding Pusur and its area, e.g. conservation field school which is established in 2015, agriculture school to prevent chemical residue, domestic waste disposal management, and tourist village. In downstream area, disaster prevention and irrigation team will manage irrigation. From this knowledge, Pusur Institute will be the institution to manage all of the activities from upstream, main-river and downstream areas.
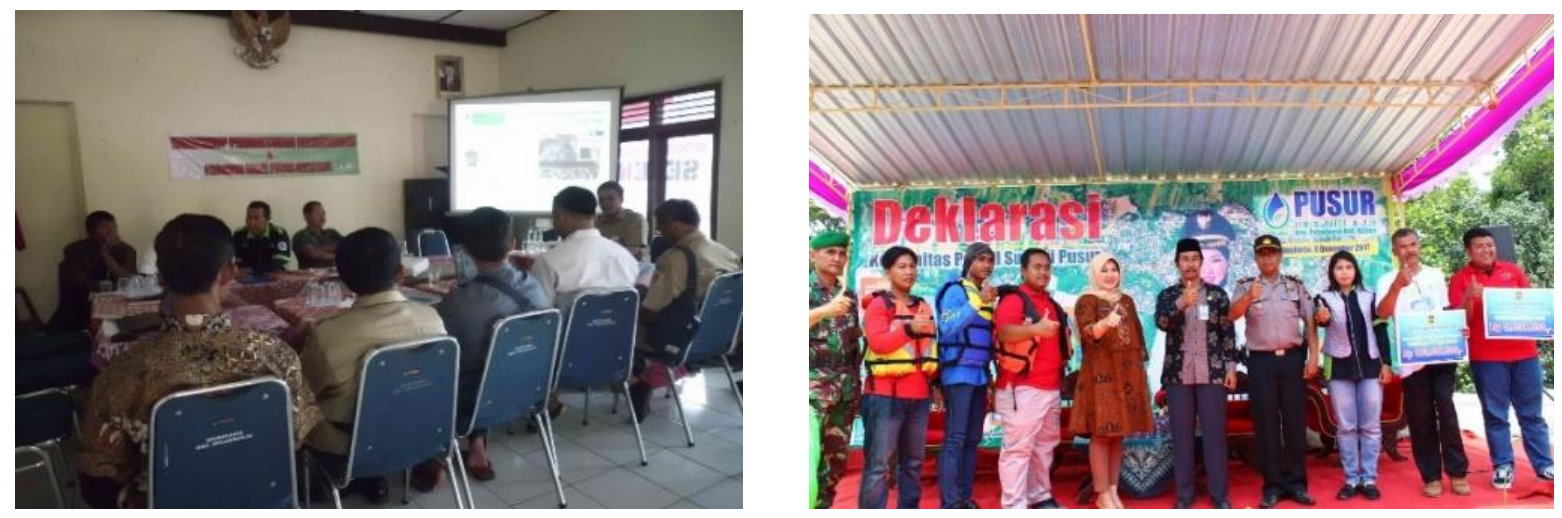

Picture 2 - The Process of Institutional Pusur Establishment

People of Mriyan refused to plant crops on their land which is considered will shift the seeded plants, tobacco and rose sowing. Indeed, people need to be explained and given the alternative solution to replace tobacco and rose sowing. Because of this problem, conservation field school was built by local government for one period. The process in operating conservation school takes a long time with systematic routine activity. There are systematic activities processes of field conservation school: (1) Early organizing by choosing the location, member, and building a commitment. The first step done by facilitator is social organizer process. Choosing a good location for field school is determining the success. The location should be strategic, easy to reach by farmer, and become a learning center for farmer. A member who will participate has to commit to do field school. (2) Identification field test as media learning. Field test is media test to find a new knowledge in field school. Field test will be a source of knowledge for farmer. (3) Learning Contract. Learning contract for field school aims to give a motivation and build a commitment together with the member of field school. (4) Make a curriculum becomes the learning object for field school which gets from identifying problem. The finding problem becomes a learning object for the process of field school. (5) Routine meeting. Conservation field school will operate periodically. The schedule is created by an agreement in the forum. Basically, it was done for one period. (6) Reflection activity. Reflection in field school will be done by participative. The purpose is to find and to see the effect of conservation field school. Basically, model of conservation field school in Mriyan village divided into 2 aspects. 
For more explanation will be explained below:

Chrysanthemum Flower School. Field school of chrysanthemum flower is not emerging because of the program brought by facilitator. It is because of the needs of female farmer group of Sekar Dewani in order to increase the number of female farmer group's capacity. In addition, it looks from the local ability. The majority of female farmer member in Mriyan village has ability in flower cultivation even though the types of flower are different. However, the treatment for the plant is not different. It begins from visiting chrysanthemum flower cultivation farmer in Kaliurang City, Sleman Regency, Yogyakarta Province. They start too curious to adopt the technology of chrysanthemum flower cultivation.
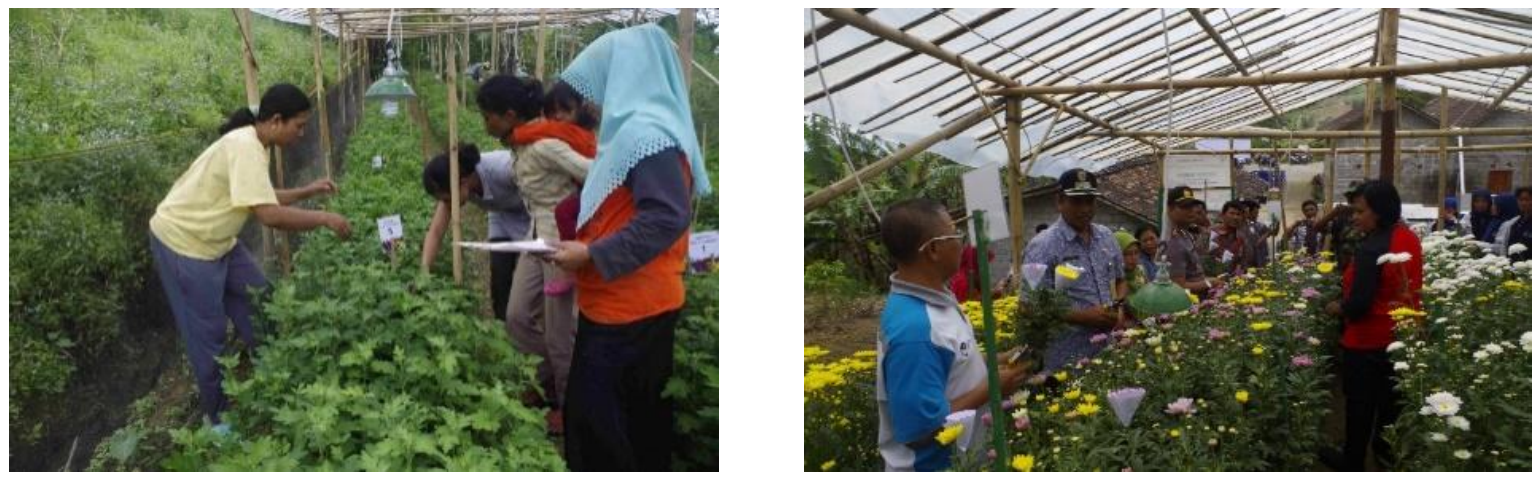

Picture 2 - Process of field school of Chrysanthemum flower in Mriyan Village

Field school of chrysanthemum flower followed by 20 farmers comes from housewife. After take care their child and house, they start to do their routine activity. Every Thursday, they gather and begin with routine observation. Start from the development, leaf condition, stem, and treatment to chrysanthemum, it will be noted in details to make sure the adaptation of chrysanthemum flower in Mriyan village land. It is still on the test category right now and the next step will be on strengthening period for the technique and business farmer. There is one facilitator comes from LPTP (Institute for Rural Technology Development) Surakarta and one expertise farmer from Kaliurang that still commit to build a network with female farmer of Sekar Dewani. Chrysanthemum flower school is held 4 months in one period. It starts from the seed selection; land manufacture, fertilization, planting, treatment, harvesting, and marketing become one curriculum.

Conservation Field School of Vegetative and Civil Technical. Farmer should find the solution to solve a critical land problem which increases year by year in Mriyan village. Since 2016, village government along with LPTP (Institute for Rural Technology Development) Surakarta tries to organize participative in order to find the alternative solution. Learn from the previous year, there is no farmer motivated to do an environment improvement with neither conservation vegetative technique nor civil technique. Hence, facilitator starts to make a step to do mentoring periodically and there should be a field test as a proof for farmer. This proof will motivate the farmer to do that kind of things. Finally, all of them formed in one media as a learning center which called as conservation field school.

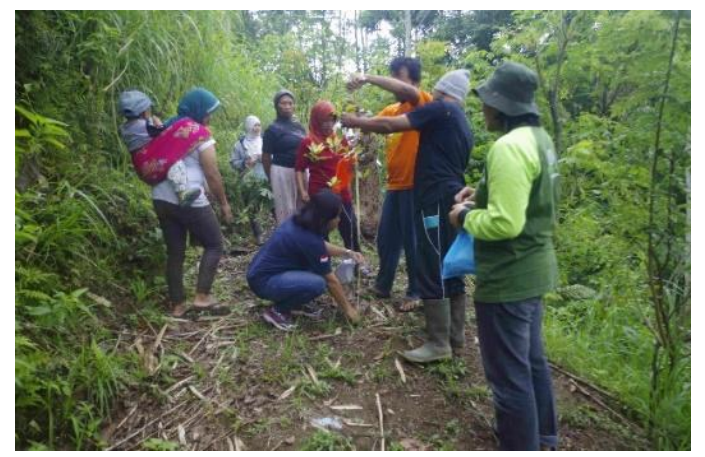

Picture 3 - The process of Field Conservation School in Mriyan Village. 
This activity is dominated by men in Mriyan village. It consists of $15-20$ farmers who active in conservation field school activity. The focus of this field school is looking for alternative solution from some problems especially critical land problem. There are 2 main activities in the process of conservation field school. (1) Understanding vegetative conservative. This activity is varied enough. In the end of 2016, there has been 1.200 plantation planted in the critical land. The types of vegetation are avocado, clove, and sengon. These types of vegetation are chosen because of the productivity and easy, it becomes an alternative solution for farmer's additional income. (2) Understanding civil technique conservation. In understanding civil technique, the activity tends to focus on land manufacture which still considers not appropriate for conservation principle. Almost 20 ha of critical land is not manufacture based on conservation principle. Technique for land manufacture still in the vertical form which means it is not cut hillside. As a result, it cause the land can't keep rain water. Rain water will go to the lower places and can't force to stay in the way it was passed. Hence, it cause the number of erosion is high. If we see from the effect, field conservation school gives several alternative solutions. In economic aspect, chrysanthemum flower commodity of conservation school directly gives some new business choices for farmer. From test land that was done, first step of chrysanthemum flower school, there is still one test land. In the strengthen technique in the second step, farmer begin to be brave to implement on their yard. The amount of adopter is 11 yard of household which uses to cultivate chrysanthemum flower. Economically, it is quiet promising for farmer. One bunch with 10 chrysanthemum flower can reach the price 10,000 - 20,000. It especially when entering to wedding season, school graduation and Ramadan. The flower demand is high. The size of $15 \mathrm{~m} \times 4 \mathrm{~m}$ chrysanthemum flower land, it can produce 5,000,000 / season.

\section{CONCLUSION}

The Conservation field school is a form of Mriyan village community participation in managing, maintaining, and protecting Pusur Sub Watershed conservatively. This participation from Mriyan community is actualized in the form of conservation field school, initiative and decision-maker, has an active role in field school (Social Learning), networking (Net Working), and human resources management. Through this things, management will affect to the sustainability of Sub Watershed Pusur, emerging collective institutional between parties to return to care to Sub Watershed Pusur, and encourage all stakeholders in maintaining Sub Watershed Pusur with the conservation principle. Two approaches to conservation field schools have an impact on capacity building and farmers' economic. From conservation side, then it appears chrysanthemum field school. From ecological improvement approach, it emerges conservation field school with the focus on the civil technical and vegetative.

\section{REFERENCES}

1. Agustinova, Danu Eko, 2015,"Memahami Metode Penelitian Kualitatif: Teori \& Praktek", Yogyakarta: Calpulis.

2. Asdak, Chay, 2014,"Hidrologi dan Pengelolaan Daerah Aliran Sungai»,Yogyakarta: Gadjah Mada University Press.

3. Bungin, Burhan, 2011, "Metodologi Penelitian Kualitatif», Jakarta: PT. Rajagrafindo Persada.

4. Chifamba, O.,2011, "Integrated Watershed Management for Minimizing Land Degradation and Enhancing Livelihoods of Resourches Poor Farmer A Case of Pungwe River Watershed», Zimbabwe, Journal of Sutainabe Development in Africa (Volume 13, No.8, 2011).

5. Creswell, John W, 2015, "Penelitian Kualitatif \& Desain Riset Memilih Diantara Lima Pendekatan", Yogyakarta: Pustaka Pelajar.

6. Data BPBD Boyolali 2014.

7. Data BPDAS Solo Tahun 2015. 
8. F. Crabtree, Benyamin dan L. Miller, William, 1992,"Doing Qualitative Research»,Sage Publications International Educational and Professional Publisher: Newbury Park: London.

9. Fakih, Mansour, Dkk, 2004,"Pendidikan Populer Panduan Pendidikan Metode Kritis Partisipatoris" Yogyakarta: Insistpress.

10. Fakih, Mansour, Dkk, 2010, "Pendidikan Popular: Membangun Kesadaran Kritis", Yogyakarta: Insistpress.

11. Freire, Paulo, 1972, "Pedadgogy Of Oppressed», Jakarta: LP3ES

12. Freire, Paulo, 2008, "Pendidikan Sebagai Proses Surat - Surat Pedagogis Dengan Para Pendidik Guinea - Bissau», Yogyakarta: Pustaka Pelajar.

13. Freire, Paulo, 2009, "Politik Pendidikan Kebudayaan, Kekuasaan, dan Pembebasan." Yogyakarta: READ.

14. Goetz, Judith P. And LeCompte, Margaret D. 1984, "Ethnography and Qualitative Design In Educational Research», Orlandio Florida: Academic Press Inc.

15. Ife, Jim dan Tesoriero, Frank, 2014, "Community Development: Alternatif Pengembangan Masyarakat di Era Globalisasi», Yogyakarta: Pustaka Pelajar.

16. Johnson, 1973, "A Trainer Guide to Andragogy, Revised Edition, Washinton DC», Washinton DC: Departement Of Health And Walfare.

17. Kirk, Jerome dan L. Miller, Marc, 1985, "Reability and Validity in Qualitative Research", London: Sage.

18. Knowles, Malcolm, 1970, "The Modern Practice Of Adult Education», London: Oxford.

19. Koentjaraningrat, 1983, "Metode - Metode Penelitian Masyarakat Pengamatan Sebagai Metode Penelitian" Jakarta: Lentera.

20. Mardikanto, Totok, 1993,"Penyuluhan Pembangunan Pertanian», Surakarta: Sebelas Maret University Press.

21. Mikkelsen, Britha,"Metode Penelitian Partisipatoris dan Upaya Pemberdayaan Panduan Bagi Praktisi Lapangan», Jakarta: Yayasan Pustaka Obor Indonesia.

22. Monografi Desa Mriyan Tahun 2016.

23. Mulyana, Deddy, 2001,"Metodologi Penelitian Kualitatif Paradigma Baru IImu Komunikasi Dan Ilmu Sosial Lainnya,"Bandung: PT. Remaja Rosdakarya.

24. Patilima, Hamid, 2007»,Metode Penelitian Kualitatif“, Bandung: Alfabeta.

25. Salim, Agus, 2006, "Teori \& Paradigma Penelitian Sosial Buku Sumber Untuk Penelitian Kualitatif», Yogyakarta: Tiara Wacana.

26. Smith, W.A, 1976, "The Maning Of Conscientacao: The Goal Of Paulo Freire's Pedagogy",Amherst: UMASS Center For International Education.

27. Suwarto dan Anantanyu, Sapja, 2016, "Improving Land Conservation in Dryland Food Crops Farming In Sub Watershed Upstream Solo, Indonesia," International Journal of Ecology \& Development, Vol. 31, Ceser Publications.

28. Theresia, Aprillia, Dkk, 2014, "Pengembangan Masyarakat Community Development (Acuan Bagi Praktisi, akademisi, dan Pemerhati Pengembangan Masyarakat,)»,UPT. Penerbitan dan Percetakan UNS: Surakarta. 